\title{
Narratives as Catalysts for Transformation and Social Action Planning within the Hong Kong Indonesian Migrant Community
}

\author{
Howard Lorne Martyn ${ }^{1}$ \\ ${ }^{1}$ Guangdong University of Foreign Studies, Guangzhou, People’s Republic of China \\ Correspondence: Howard Lorne Martyn. E-mail: howardeap@gmail.com
}

Received: April 1, $2018 \quad$ Accepted: April 10, $2018 \quad$ Online Published: May 28, 2018

doi:10.5539/ass.v14n6p106

URL: https://doi.org/10.5539/ass.v14n6p106

\begin{abstract}
This paper discusses the use of written and oral narratives, composed as classroom assignments by adult Indonesian migrant workers, sojourning in Hong Kong. Individually written narratives embody group-common elements that can be acted upon, thus becoming catalysts for personal growth and for group social action planning. Personal growth includes refocusing personal identity away from the societally imposed and devalued 'domestic helper', toward identities that offer self-empowerment. Redefining personal identity within a group learning situation also builds group identity which can be directed toward confronting hegemonic forces. This is done on four fronts: firstly, by claiming the symbolic right of cultural space and by demanding respect within the larger Hong Kong community; secondly, by publicly agitating against government policies, such as human rights and minimum wage legislation, that migrant workers believe disadvantage them; thirdly, by increasing ability in English, Cantonese, and basic computer applications that specifically meet Indonesians' work requirements and interests; and finally, by building the capacity to confront employers in claiming government guaranteed minimum wages and rest days. Through these actions, the opportunity for both personal and societal transformation is created.
\end{abstract}

Data was collected through journal narratives and semi-structured qualitative interviews with migrants who were taking weekly English languages classes at a small private training center in Hong Kong.

Keywords: adult non-formal education, Indonesian migrants, labor globalization, migration in Hong Kong, narrative analysis, transformational learning

\section{Introduction}

Since the 1950's there has been an overwhelming amount of research conducted on cross-cultural adjustment. Historically most literature has been informed by psycho-social models of culture shock (Oberg, 1960, pp. 8, 23; Winkelman, 1994), models relating to cultural learning and communication (Barna, 1972, 1976; Sobre-Denton \& Hart, 2008), models relating to psychosocially induced stress and coping mechanisms (Slavin, Rainer, McCreary, \& Gowda, 1991), and models related to identity theory (Deaux \& Martin, 2003). Studies are replete with examples that have taken place within the contexts of student exchanges (Nyberg \& Jensen, 2009; Sovic, 2009; Zhou, Jindal-Snape, Topping, \& Todman, 2008) and company transfers of executives to offshore sub-offices (Ali, Van der Zee, \& Sanders, 2003; Friedman, Dyke, \& Murphy, 2009; Hyder \& Fregidou-Malama, 2009; Wong, 2001). Moreover, cross-cultural adjustment models have most often been applied in situations of relative equality between the dislocated individual, and a large section of the population of the host nation. The socio-economic status of the sojourning student or executive, is, generally, considered in a positive light, by citizens of the host nation, where they are often believed to uplift moral, cultural and economic 'tone'. This is especially so of executives, with immigration laws that do not out rightly preclude, for example, the possibility of eventual permanent residence, or marriage with host nationals. This is in contrast with legislation, in Hong Kong, for example, that specifically prevents migrant workers from permanent residency and work in the informal sector, and in Singapore, for example, that prevents marriage to host nationals, and where pregnancy of migrant laborers subjects them to deportation (Lyons, 2006, pp. 8, 23).

This paper examines the situation of labor migrants from the 'global south' to a region of the 'global north', specifically Indonesian migrant workers sojourning in Hong Kong, and the use of narrative methodology as a catalyst to refocus their locus of identity, away from the externally imposed and statically defined 'domestic worker' and toward psycho-social transformation. Integral to this transformation is both individual and group 
identity building which together reify into social action. In addition, I wish to illustrate how migrant workers who are enduring hegemonic forces may find a voice of resistance through redress to government authority, and through planned group collective action.

The theoretical significance of this paper lies in bringing together the fields of narrative inquiry and transformational learning. Participant written narratives act, in situations of dissonance, as catalysts for group discussions and transformation, leading to expanded or replaced cultural frames of reference. In practical terms, participants undergoing stressful cross-cultural life experiences learn to control situations and become assertive through an expanded or replaced cultural frame of reference.

\section{Conceptual Framework}

The conceptual framework for this research is illustrated in Figure 1, with a flow from cross-cultural dissonance, toward an expanded or replaced cultural frame of reference. Issues of cross-cultural anomie may be thought to reside under what Mezirow $(1996,1997)$ refers to as a "disorienting dilemma", which, he believes, is a prerequisite for individual transformative learning. Transformational learning itself is the process of "effecting change in a frame of reference ... structures and assumptions that shape and delimit expectations, perceptions, cognition and feelings" (Mezirow, 1997, p. 5). The frame of reference is composed of two dimensions: habits of mind and points of view. Mezirow cites, as an example, ethnocentrism and cultural centrism as a habit of mind, and negative feelings that may arise regarding those who are ethnically or culturally different as examples of points of view. These positions may be challenged through communicative learning which requires critical questioning of assumptions underlying intentions, values, beliefs and feelings. The transformation from one frame of reference to another requires a "disorientation dilemma" and often occurs within challenging discourse. Effective cross-cultural adjustment and acculturation may result from action taken after discourse, in which one's worldview is challenged, expanded or replaced.

Written narratives provide the context in which habits of mind and points of view are evident. Riessman (2008) considers thematic analysis most useful when considering meaning, and examining motivations and perceptions within a specific context. In applying thematic analysis, it is necessary to consider changes in attitude and situation over time and place. Bakhtin's chronotope types (Kiernan, 2010) in conjunction with Gergen and Gergen's narrative temporal structure (Daiute \& Lightfoot, 2004) allow the imposition of plot development onto time and place. The consideration of time and place is fundamental to thematic analysis, "not so much [as] background information as semiotic coordinates for establishing identity" (Kiernan, 2010, p. 87). The formation of identity is bounded by time and place, with new inputs to identity occurring with substantial changes in those dimensions. Thematic analysis of written narratives, discussed in group situations may lead participants to discover new ways of coping with stressful life situations.

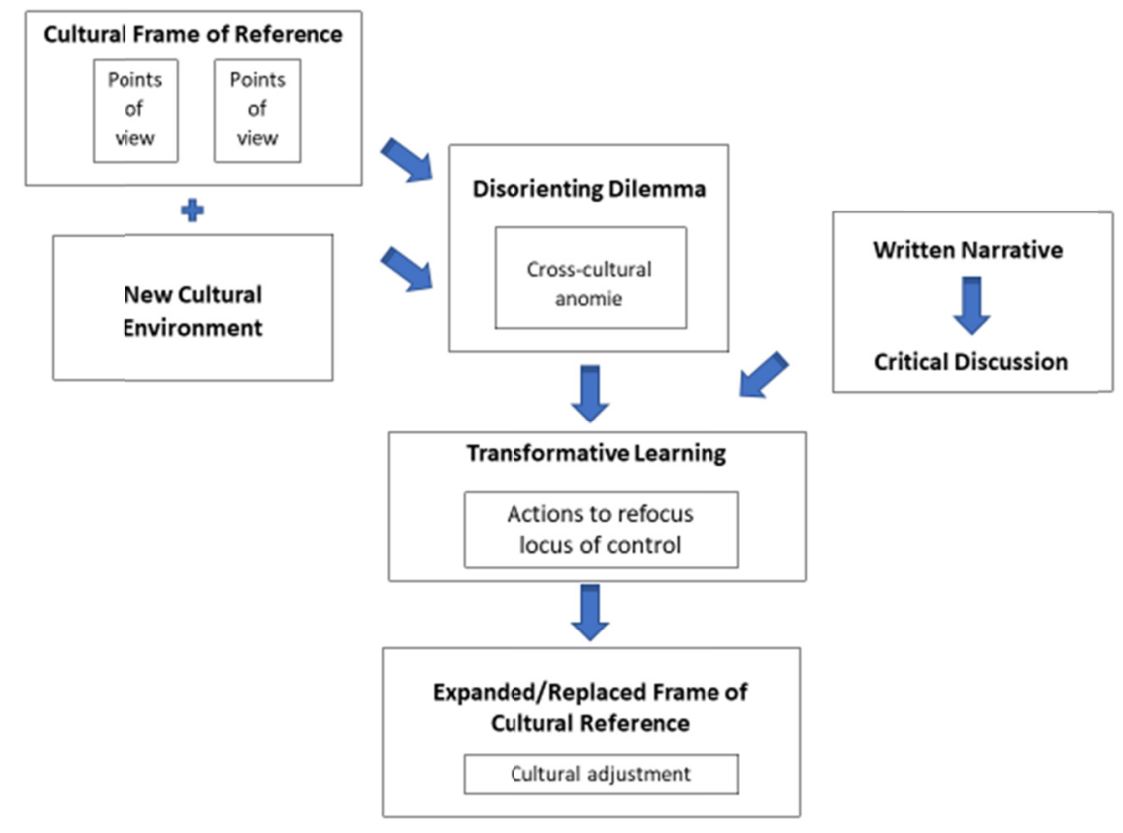

Figure 1. Conceptual framework 


\section{Situation}

Since the late 1990s Indonesian migrant workers in Hong Kong have felt a need to establish communities corresponding to religious, cultural, and economic interests. Numerous groups have sprung up in answer to these needs, many of which joined an umbrella organization, The Coalition of Indonesian Migrant Workers Organization (KOTKIHO). KOTKIHO was established in 2001 as a coordinating body, with the mandate of responding to common issues and providing programming for member organizations. Programming centers on the provision of educational and training courses that meet various member needs.

KOTKIHO operates from a flat in Causeway Bay, Hong Kong, close to a large park, where Indonesian migrants congregate on Sundays, relaxing with friends, and occasionally participating in, or watching, Indonesian cultural performances or rallies. The organization also operates a safe-house for domestic workers who have pending court cases, usually against employers for breaking Hong Kong labor laws. Funding comes from numerous charitable NGOs, fund-raising events, and regular weekly English language and computer training classes.

Education and training classes are held on Sundays with programs running from 9 a.m. to 8 p.m. Regular programming consists of three 2-hour English language classes, and three 2-hour computer literacy classes. These are occasionally interspersed with Cantonese language classes and discussions concerning program planning, religious, legal or human rights issues, sometimes lead by guest speakers.

\section{Method}

Over an eight-year period I taught Indonesian women basic English language reading, writing and conversation skills in 2 hour classes, in 10 week cycles. In addition, during each of these cycles I asked my participants to write narratives as homework assignments. These focused on two areas; firstly, aspects of their pre-departure lives, often relating to the management of their migration decision and to values and cultural expectations in their home communities, and secondly; aspects of their lives in Hong Kong, focusing on required cultural concessions and how these have impacted on relationships and identity forming dimensions such as self-esteem, life-control, and feelings of connectedness with individuals and cultural organizations to which they might belong. Although the particular details of a participant's entry belong to an individual, group-common themes often emerged. Critical incidents, drawn from narratives that had the potential for transformative learning were, with permission, discussed in class. Critical incidents were often expressed as impacting on self-esteem and the financial security of the participants' families in Indonesia.

Participants wrote sporadically, some for a few weeks, others for several months; in fact, long past the end of the 10 -week teaching cycle. Occasionally their writing took the form of poetry and commentary on photographs that were included in their journals. Although narratives can embody a variety of forms, including the interpretation of photographs and other artifacts, I have chosen to confine this article to participants' oral and written comments relating to their deployment in Hong Kong.

The disorienting dilemmas described became the catalysts for group discussions and action planning designed to re-establish the individual's locus of control; to build their capacity to conduct negotiations in work situations, to operationalize the right to claim legally guaranteed employment benefits, and to gain control over situations that cause cultural anomie.

\section{Working with Narratives}

While working within an English as a Second Language (ESL) environment, I was cognizant of KOTKIHO's role in building a community based on shared experience for social action; individual stories provided a space for refocusing identity and for collective decision making. Polkinghorne (1988) describes the ideal narrative as a "gathering of events into a meaningful story ... through which life events are conjoined into coherent, meaningful, unified themes" (pp. 126, 131). Polkinghorne points out that narration should be more than simply a recording of events; or more even than a recording of events with analysis. It is the creation of personal identity, the construction of events, and perhaps most importantly, the allocation of merit or noteworthiness. Many narratives, especially in an ESL context, are less than unified and require rewriting to achieve coherence. But no matter how grammatically wanting (within an ESL context) and stylistically crude, the allocation of merit or noteworthiness to one's lived story always demands respect within an emancipatory context.

Clandinin and Connelly's (2000) simply put truism was our grounding: "Why narrative? Because experience" (p. 50). Clandinin and Connelly (1994), expanding on Dewey's belief that narratives must be contextualized within situation, continuity and interaction, feel that narratives should also reach inward to our hopes, feelings, aesthetic and moral values; in effect establishing the locus of identity control, as well as extending outwards, affecting the reader and in so doing create the possibility for social transformation. Narratives are bound to memory and are 
thus temporal, just as they are bound to place. While economic, political and social histories have come together at a given place and time to make migration the clear alternative, those forces always bring about discontinuity, dislocation and uprootedness. They strain relationships and tests moral values. Economic and social injustices often precipitate. Common memory, revealed through narratives of time and place, reveal injustices and form catalysts for social action designed to recapture agency, relocating it within the individual, a process "likely to invoke strident forms of reawakening" (Niezen, 2004, p. 40).

The examples illustrate themes of searching for independence, negotiating with employers, underpayment and negotiating with community members. These themes dominated participant writing concerning the Hong Kong segment of their sojourns. The written narratives in the remainder of this paper are authentic. Word choice and grammatical changes have been made only when clarification was necessary.

A. Ester ${ }^{1}$ : The manager lets me sell phone cards and beer. Soon the dress shop will be mine.

B. Salama: A small plot of land. My future in vegetables.

C. Yasmin: Include me on the graduation list. Money is no object.

D. Talia: A space for my dishes. I'm not a virus.

E. Oriana / Yolanda: What can I do with $\$ 200 ?^{2}$ My sister needs a bicycle.

F. Marcia: Being sensitive about local issues. It isn’t just about us.

\subsection{Searching for Independence}

\section{A. Ester: The Manager lets me sell Phone Cards and Beer. Soon the Dress Shop will be Mine.}

Most participants managed to save very little money during their sojourn, though a few did save toward the purchase of small Indonesian businesses. Financial issues and the quest for financial independence were major themes throughout Ester's journal. Over a one-year period she became involved in multi-level marketing and was trying, unsuccessfully, to save money to start a small business. Ester explained her desire for financial success:

I want to prepare my future. I want when I become old still have a lot of money and make my children happy in their future ... My grandparent very poor. My parent also poor. When I was small child I also poor. Now I am young also still poor. What about my children in the future?? I don't know yet.

Ester explained that, as a small child, she was very poor in comparison with her neighbors. Her parents worked as indentured laborers on a farm. They kept enough rice and soy beans for their own use, with a little extra to sell in the market. Ester described a cycle of unbroken familial poverty which she was determined to end. On her day off work she attempted to earn extra money by selling long-distance phone cards to other Indonesians through a small Indonesian company operating in Hong Kong. She earned a profit from each card sold and was promised a share in company profits, on a multi-level marketing basis. At first she was quite positive about the scheme.

Now my manager promises I can make future profit if I work selling to my friends on Sunday. I can make more money if sell during holiday. I need to work hard because don't want to be poor like before. This business give good opportunity. Boss is good man. I think I can save for my good future in this way.

Over time, however, Ester's estimation of her potential success dwindled. Four months after selling phone cards she had made a small amount of money and was considering looking for other ways to earn more money.

I now making sometimes \$100 each Sunday, sometimes \$200. Friends know I sell phone cards, so they will look for me if they want to buy. Sometimes they hide from me because they know I want to sell. I don't want to push them too hard because they are friends. This business ok but not enough money for me. I need find something else.

Ester found more success when she stopped selling phone cards just among her friends and started selling them in bars frequented by Indonesians on Sunday afternoons. Ester mentioned that her employer sanctioned her attempts to improve her financial situation. She was able to combine selling phone cards with selling drinks for commission.

Now things better. Have good employer who pay me every month and let me be free all day Sunday. Employer don't mind I do this business because they know my background. I now free to sell phone cards in bar. Manager know me so let me sell drinks. Now make $\$ 400$ every Sunday. After two or three more

\footnotetext{
${ }^{1}$ All participant names are pseudonyms

${ }^{2}$ Money is expressed in Hong Kong Dollars: 7.8 HKD $=1$ USD
} 
years I have enough to buy dress shop.

Ester had found what she believed to be a viable way of earning extra money for the purchase of a business. Both in her journal and in conversations, she appeared positive about her ability to adapt to the informal Hong Kong work environment and eventually find financial success.

Contracted labor migration is mediated by numerous individuals, companies, government agencies, and government departments in both sending and receiving countries. The extent to which participation in informal work is necessary often depends on the combination of effects these entities produce, over which the migrant has little control. In the case of Indonesians entering Hong Kong, required brokerage fees, training fees, transportation fees, insurance fees and placement fees, may pressure her to take illegal informal work on her day off, thus placing her in a possible deportation situation.

Rural - urban and 'global south' - 'global north' migration has become a contributing factor to relationship building, networking, and employer-employee relationships in mega-cities throughout the world. Scholars believe this is changing the very nature of city life. Bayat (1997) for example, links the rise in migration in Latin American and Middle Eastern cities to debates about what constitutes democratic entitlement in 'civil society'. Commenting upon rural-urban migrants in Asia's less developed cities, Bayat asks at what point "will their sheer cumulative numbers transform them into a potential social force" (p. 58). At what point, we may ask, will migrant demands for what they consider to be democratic civil entitlements, become part of the social contract?

Many migrants, such as Ester, are unavoidably caught between the paternalistic forces of traditional economic arrangements in Indonesia and modern assumptions of entrepreneurship in Hong Kong. Migrants are often forced into the informal sector to meet family financial obligations, yet in doing so, are breaking Hong Kong Immigration law ${ }^{3}$. This has, to a large extent, removed personal agency from the hands of the migrant; she cannot return home, because to do so would give her no way to service her debt, and she is not allowed to take on menial work, or in doing so, she makes the decision to break immigration law. Goss and Lindquist (2000) in their study of Asian migration point out that present day migration mechanisms are remarkably similar to the indentured labor arrangements of centuries past, though in the Indonesian case, the regional Emir who would have sent laborers to domestic or foreign areas of labor shortage would have retained a moral obligation toward his charges, something that does not exist today.

\section{B. Salama: A Small Plot of Land. My Future in Vegetables.}

Home ownership was regarded as tangible evidence of migrants' sojourn, giving validity to the years away from their family. Participants sometimes expressed a desire to buy a house in their village. A few had entered into agreements to either purchase homes or renovate relatives' homes.

Over a two-year period Salama discussed her future ambitions and wrote about her quest for independence. During discussions about future ambitions, she would proudly describe the purchase of a house her father had negotiated on her behalf, and her attempts at contributing toward the monthly payments.

I think my house is not really big and it's just nice for me. It's 3 bedroom, 2 living room, 1 kitchen, dining room and 1 bathroom. Actually, that is my relative's house. Relative from my father side. Because they wanted to move to other place so they will sell that house. My father offer it to me and I think I have enough money to buy so I asked my father to do it for me. It's about $\$ 45,000$. It's really big sum money but I try my best to save money so that I can have it. The house is near to my parents.

Periodically, Salama would comment on the importance of this purchase in terms of future financial security.

I now pay $\$ 1,000$ every month to my father. He pay this to my uncle so in a few years I will own house. The house is on small road in Semarang just by my father's house. When house paid for I will return and live there. When I own house no need to worry so much about work because I will have place to live, so nothing bad will happen. Maybe I can live with father and rent the house if I don't have job.

Almost two years after purchasing the house Salama began to expand her plans from home ownership to land ownership. She saw this as financial investment to secure her future independence.

Nearby house is small plot of land owned by my uncle. He wants to sell the land, same as my house before. I can pay my father $\$ 400$ each month for the land. Maybe later I plant vegetables for sell in the market or maybe I rent the land. This very good for my future.

\footnotetext{
${ }^{3}$ In Hong Kong, as in many other regions, there are no legal income generating opportunities open to migrants outside of work within the contracted employer's home. Migrants who engage in informal work activities in Hong Kong are subject to deportation.
} 
Salama was a very forward-looking person who seemed well motivated to secure her future independence through house and land ownership. Over an extended period she maintained a very positive outlook about Hong Kong, her employer, her work and her future life in Indonesia.

Land ownership, both as a personal residence and a place of business remained a high priority for Salama. She saw herself as temporarily in Hong Kong at this juncture of her life, but her identity emanated from a village on the outskirts of Semarang, Central Java. In her writing Salama would locate her future in terms of time, place, family and friends in the environment she knows best. She, as well as many other migrants, cope with their longing for home, by framing life in terms of the migration experience; life before migration—childhood, school, adolescence, young adulthood; the sojourn - employers, adjusting to a new lifestyle, planning for the future; and the anticipated return home - reunion with family, marriage, and children, work responsibilities. Having planned for a future in Java, the here and now demanded that Salama settle into her surroundings, make friendships and establish a temporary life in as comfortable a manner as possible; a task that, may not always be successful since migrants may be separated from the familial continuity and village tradition that provides psycho-social stability. Although Salama's adjustment to life in Hong Kong was not as stressful as others', she did miss home and family as evidenced in a poem written shortly after her return to Hong Kong from a bi-yearly visit to Java:

Day by day my time pass by

There's something left behind

My feeling and my mind

My home and happy place

The room I call my space

But most of all I miss

My sisters friendly kiss

My friends being all around

I hope I'll soon be found

And taken back again

In her poem Salama describes missed family and friends, people from her village and the intimate relationships that village life and living with extended family entails. Bell (1997) discusses the "sense of the presence of those who are not physically there" (p. 813), metaphorically as "ghosts", or associations of place with specific people who are no longer physically present, and how, when returning to such a place, the essence of the displaced are felt to varying degrees. In Salama's case it is not the family and friends who have 'disappeared', but herself, deployed to a foreign environment, living with strangers, and wishing for "the room I call my space". Salama's attachment is to home, family and friends; the familiar from which her identity has been formed, and to which she will return.

\section{Yasmin: Include Me on the Graduation List. Money is No Object.}

Hopes for an independent future sometimes centered on education. Participants occasionally linked future education to independence, but of these, Yasmin was remarkable for her level of dedication in the face of family hardship. Over an 18-month period Yasmin, an English language teacher at KOTKIHO, discussed her desire to upgrade her education and become a professional teacher. Despite having to quit school one year short of high school graduation, the good quality of her self-taught grammar, pronunciation and classroom management skills became self-evident during classes she and I co-taught. Yasmin was a single parent and hoped to take formal teacher training classes upon her return to Indonesia but knowing she would not be accepted by a university, paid to be included on her school's graduation register. In discussions she pointed out:

I had to quit school in my last year of high school. This wasn't my fault. My mother was having terrible troubles with my father when I was 16 . He abandoned us. I really hate him for that. My brothers and parents were fighting constantly. I couldn't go on at school, so I quit. Later I paid $\$ 3,000$ to the principal, so I could be included on the graduation list. Otherwise I cannot get into teachers' college.

Yasmin had expressed two major reasons for working in Hong Kong. These were to save money toward the tuition at a teachers' college in Indonesia, and to send money home to her mother who was looking after her 3 -year-old son. She often mentioned furthering her education within the context of being able to provide for her child.

I'm sure I could be a very successful teacher. I really want to go to teachers' college when I return so I can 
earn money to look after my son. I've almost saved enough money for the tuition and to support myself and my son for a couple of years.

Several times Yasmin expressed the importance of voluntarily teaching at KOTKIHO. Through teaching she had found a community of practice and support group as well as a life-purpose; a profession to which she could readily dedicate herself. She adapted well to the KOTKIHO teaching environment, and that in turn helped her to adapt to Hong Kong because it gave her self-confidence that carried on into her involvement in migrant advocacy work and in dealing with the community at large.

I'm teaching 6 hours on Sunday now. That's crazy. [Training manager] has really gone too far. No one else is willing to teach so much but it's ok because I'm really having a good time. [Training manager] asked me to teach another basic class from 6 to 8. That class seems to have better skills. Most of them went to secondary school so their writing isn't too bad. I'm teaching them more complicated sentence construction and I'm using worksheets using Michael Swan's grammar book.

I spend almost all my free time here [at KOTKIHO] now. Last Sunday I was here till after midnight. I'm really lucky because my employer doesn't care. She just says if I do a good job from Monday to Saturday she doesn't care what I do on my day off. Sundays are my days.

Eventually Yasmin decided to take a six-month Montessori training course, offered in Hong Kong by the Canadian Montessori Association. She believed this would provide a suitable qualification for work as a kindergarten teacher when she returns to Indonesia.

I can do the course in Hong Kong and earn a good salary at the same time, so I can support my family. My employer supports this idea too. In Indonesia there is no guarantee I will be accepted to a college. They will want extra payment because I have been working abroad. But I am missing my kid's childhood.

Although Yasmin complained about being overworked, this was done with a tinge of pride at being asked to teach extra hours and being recognized for her abilities. Wenger (1998), like other post-modern theorists views identity as fluid, constantly shifting, and without solid boundaries, though soft, elastic boundaries may emerge through identification with communities of practice, organizations, formal and less formal affiliations and relationships. Yasmin negotiated a hoped for future identity by consolidating factors of past circumstances, over which she had little control, and present associations aimed at testing her suitability for a future community of practice. These would hopefully come together in a "cascading interplay of participation and reification [through which] experience of life becomes one of identity" (Wenger, 1998, p. 151).

\subsection{Negotiations with Employers}

\section{Talia: A Space for my Dishes. I'm Not a Virus.}

Talia described humiliating situations, designed to clarify and strengthen the hegemonic relationship imposed by her employer. She described incidents that were emotionally hurtful to her, for example, her employer insisted on keeping Talia's food and eating utensils, separate from her own:

I have special space for washing my own dishes. I can't put [my dishes and eating utensils] with [employer's] dishes. Cannot put my food with her food. Then I felt I'm just like virus for her.

Talia described actions conducted by her employer that she believed had no other purpose than to humiliate her.

After cleaning floor and using wax [employer] wait for 30 minutes. Then she take white cloth and wipe under chair or couch. If any dust she will be angry and telling me she will terminate me. But really, I do good job.

In addition, Talia felt that she was hindered in participation in community activities because her employer did not give her the 24 hours of continuous rest each week as required by Hong Kong labor law, limiting her free time to Sunday morning and afternoon. Lack of time prevented her from taking an official position in the cultural dance group to which she belonged, and limited participation in civil society.

I can leave home after making breakfast. Then go to practice in park with other Sanggar Budaya [Indonesian Dance Group] members. But must be home by 4 p.m. to make supper. Sanggar Budaya members asked me to be club secretary but cannot because no time. They ask me to do evening performance with them but cannot.

Talia seemed to have a mixed relationship with her employer. She took care of an elderly family member, 'grandma', as well as a middle-aged couple. Although she believed her employers were fundamentally good people, she described comments that she thought were either thoughtless or designed to belittle her. Talia wrote about comments made in a Laundromat. 
Grandma asked me about the clothes I had washed in the laundry ... I said that I needed to wash my clothes because it was already 5 days I didn't wash it. But she became angry. She said I have to use my own money. She scolded me in front of CiCi's [her employer's] husband. I was so ashamed.

Talia believed that the real issue was not the few dollars she saved by washing her clothes with her employer's, but that she had mixed her clothes with her employer's clothes. She interpreted 'Grandma's' words as racist, just as she had interpreted her employer's desire to keep eating utensils separate, as racist. Clarification of meaning, and cross-cultural sensitivity on the part of both Talia and her employer seemed to be lacking, something that Talia had not been expecting. Black, Mendenhall and Oddou (1991) in their "Framework of International Adjustment" assert that the adjustment process begins at the pre-departure stage with individual training, previous experience and careful candidate selection. It then carries on at the deployment stage with individual skills such as relation skills and perception skills, job skills such as role clarity and role conflict, organizational skills such as logistical support and finally involves non-work areas such as family-spouse adjustment. The anticipatory adjustment and in-country adjustment phases described, closely match participants' narrative descriptions of issues which were likely to cause cross-cultural adaptation problems. Participants identified pre-departure training as a major source of misinformation or simply where strategic information that could have relieved cross-cultural difficulties was not given. The miscommunication between Talia and her employer indicates a training need at the pre-departure stage. Pre-departure training, although required, is effectively unregulated in terms of content in Indonesia, something that migrants' rights groups in the country have been lobbying to change.

\subsection{Underpayment}

\section{E. Oriana / Yolanda: What can I do with \$200? My Sister Needs a Bicycle.}

Participants described situations in which underpayment impacted on their ability to meet family obligations, and situations in which they were intimidated into accepting reduced rest days. These situations sometimes lead to severe discontentment with the migration experience for some participants.

It was especially difficult for those who spent their time looking after other people's children, when the parents of those children withheld salary, thereby preventing the participants from providing the only visible demonstration of their love for their own family-money. The promise of money was the compensation for sacrificing the nurturing emotional labor demanded of women in Javanese villages. When that promise was not fulfilled, due to underpayment, it did not simply result in a lack of spending money for participants, but more importantly often prevented them from demonstrating familial love and fulfilling their duties as primary breadwinners.

Research by the Asian Migrant Centre (2005) indicated that approximately 10 percent of Indonesian domestic workers were paid between $\$ 1,800$ and $\$ 2,000$ per month, just under half of the government approved monthly salary of $\$ 3,740$ (The 2018 monthly salary is $\$ 4,410$ ). Anecdotal information from 2017 suggests that this is unchanged. Oriana had been told by training center staff in Indonesia that she would be paid $\$ 1,800$ per month as she was inexperienced and had not completed secondary school. In addition, her employer did not pay her on time (inconvenient, though not illegal as long as the full salary has been paid within seven days after the end of the month). After a few months with her employer she indicated how underpayment and late payment affected her ability to assist her family. She had promised to buy a bicycle for her sister in Indonesia but could not, due to her employer's delay in paying her salary.

I have promised . . . to send money [to family in Indonesia] to bought bicycle go to school my younger sister but my employer not give [salary] yet. Before leaving house, I tried waiting my employers wake up. I waited one hour. I telling them I need money for course [KOTKIHO English course] and for buy sister bicycle. Employer give me $\$ 200$ [about $8 \%$ of the money owed to her]. I want to cried. What can I do with $\$ 200$ ?

One-week later Oriana still had not been paid:

My employers had promised to give me salary, but she talk lies ... she just give one hundred.

Oriana received her (illegally low) salary 3 weeks after the due date.

Yesterday she paid me $\$ 1,500$. With other $\$ 300$ I now got full salary. Every month is same thing. Why I have to complain to get salary?

Another participant, Yolanda, had moved to Hong Kong from Purwokerto, Central Java. When Yolanda joined our class, she had been in Hong Kong for two months. As in the case of Oriana, Yolanda had been told by Indonesian training center staff that she would be paid $\$ 1,800$ per month. After arriving in Hong Kong, she was 
delighted when her employers offered to pay $\$ 2,000$. Soon afterward, however, she was disheartened to learn that, in fact, the minimum wage was $\$ 3,540$. Still, in other respects the employer treated her well, and she was making more money than she had anticipated. In her journal she wrote:

I work for a good family with two kids. They cannot afford to pay me the minimum wage, so I receive only $\$ 2,000$ per month.

Initially Yolanda did not see a discrepancy between a good employer and underpayment, but rather, saw a bond in the common situation of financial hardship. However, some months later, she did indicate some animosity toward her employer for underpaying her.

I understand their situation. They live in public housing estate and have little room. They are not rich people. But I think it unfair that I told $\$ 3,540$ when really $\$ 2,000$. If $\$ 2,000$ should tell while still in Indonesia, not after here and expecting more money.

The opportunity for an egalitarian cross-cultural adaptation to Hong Kong had been compromised from the pre-departure stage when she had been misled about her salary. She had been preparing for departure under the purposeful misguidance of her Indonesia based recruiter and training center staff. Yolanda's initially positive comments about her employer, and Hong Kong employers in general, became pessimistic over time.

They can be very nice, but they don't think about my situation. I come from very poor family. Why they not pay me full salary when so little to them but so much for me?

After 18 months with the same employer Yolanda wrote:

I think I should leave my job and move into shelter. If leave employer I can write letter to immigration about my situation. Maybe I can get money back for underpay.

She was now in a two-year contract from which she could not easily extricate herself, without going through the hurdles of a Labor Tribunal hearing and months of living in a shelter with no income. Even if successful in a hearing, she would have to return to Indonesia and begin the entire recruitment process anew.

\subsection{Negotiations with Community Members}

\section{F. Marcia: Being Sensitive about Local Issues: It isn't just about Us.}

Participants reported both perceived kindnesses and perceived hostility in casual daily encounters outside the employer's home. All participants felt that at some time during their sojourn their ethnic background had affected others' attitudes and actions towards them, either positively or negatively, but Marcia felt that it was the duty of the migrant to garner positive community support.

Marcia seemed to have very good casual relationships with both prominent and non-prominent community members. As leader of one of the largest grassroots migrant organizations in Hong Kong she would, from time to time, be involved in meetings with Hong Kong legislators. She felt that she was treated as an equal in her discussions with them.

We met Emily Lau [a Hong Kong politician] today. She's one of our supporters, actually. We discussed the discrimination legislation and how it doesn't address minority religions. It was a good discussion and she promised to try to do something about that issue.

Similarly, Marcia felt she had good rapport in her casual meetings, such as with shopkeepers. She felt this was because she went out of her way to be a good role model for Indonesians in the community.

Some migrants are not very good at working with local people. They have no consideration for the problems of the ordinary person. He has problems and has to make a living ... has to send his kid to school and pay bills. We have to consider those things. Migrants' rights isn't just about us. We have to be sensitive about local issues too.

\section{Discussion}

In groups we discussed overcoming hurdles. One participant, an ardent pacifist, pointed out that she could not be involved in aggressive confrontation. In response Yasmin asked, "Will my sister not get an education because I cannot buy her a bicycle, and will my daughter be in my situation 20 years from now?" Most participants concluded that, yes, that would be the likely result, unless they could take action, which would occasionally be confrontational, to prevent it.

\subsection{Issues Identified in Narratives}

Clear breaches of immigration and labor law, were first identified. These are summarized in Table 1. 
Table 1. Incidents and laws broken

\begin{tabular}{ccc}
\hline Individual Narrative & Group-common Identified Incident & Violation \\
\hline Talia & Withholding 24 hours continuous rest per week. & HK Labor Law \\
Oriana & Underpayment/Late Payment & DH Contract (Immigration Law) / \\
Yolanda & Underpayment & HK Labor Law \\
\hline
\end{tabular}

Note: $\mathrm{DH}=$ Domestic Helper, ID=Immigration Department

Group-common issues, from which we could build capacity through participant training, were then identified. These are summarized in Table 2.

Table 2. Narratives and group-common issues

\begin{tabular}{cc}
\hline Individual Narrative & Group-Common Identified Issues \\
\hline Ester & "I want to prepare my [financial] future" \\
Salama & "I try my best to save money" \\
Yasmin & "I really want to go to teachers' college" \\
\hline
\end{tabular}

Finally, instances of perceived hegemony were identified. These are summarized in Table 3. We realized that such instances could not likely be directly stopped, but their psycho-social impact could be lessened, and, to a lesser extent, their frequency could be reduced with training, through public socio-cultural activities aimed at educating the general public.

Table 3. Hegemonic incidents

\begin{tabular}{cc}
\hline Individual Narrative & Group-common Identified Incidents \\
\hline Talia & "I'm just like a virus for her" \\
& "She takes white cloth and wipe under chair" \\
& "She scolded me for mixing my clothes with hers" \\
\hline
\end{tabular}

\subsection{Group Suggestions and Outcome}

\section{Talia}

Talia faced breaches of labor law, as well as hurtful accusations from her employer, which she took to be racist. Although migrants are entitled to 24 hours of continuous rest per week, this Labor Law is commonly broken. Typically, migrants are allowed to leave their employer's home (where they are required by law to reside) Sunday morning but must return by Sunday evening. Based on experience, participants knew that a formal complaint to the Hong Kong Labour Department would take 9 to 12 months to process and would not likely result in compensation. A less aggressive stance was adopted with group members suggesting that Talia write a formal letter to her employer, explaining why she needed time off, and subtly reminding her employer of the legal entitlement. The class drafted the letter together. Talia's employer agreed to extend the curfew by four hours, thereby giving Talia time to participate in Sanggar Buddiah cultural activities.

\section{Oriana}

Oriana was at the beginning of her two-year contract and considered quitting her job, moving into a shelter and reporting her employer to the Hong Kong Labour Department. The group advised her against this, however, as being tactically unwise. The recommendation was that she wait until her $\$ 21,000$ debt had been paid, and a longer history of underpayment could be established, before taking action. However, it was also suggested that Oriana point out to her employer minimum pay requirements. As a result of following group advice, Oriana was fired. She moved into a shelter while waiting for a Labor Department tribunal to resolve the case. Although she eventually was compensated for underpayment, she did not receive compensation for loss of employment, nor did her employer have to pay punitive damages.

\section{Yolanda}

Since Yolanda had paid off her placement debt, participants advised her to break her contract, move into the shelter, and write a letter to the Hong Kong Immigration Department detailing her underpayment. We composed a draft of the letter in class and asked two migrants to go with Yolanda to the immigration department to present the letter. After 10 months, Yolanda confronted her employer in court and was awarded the entire amount 
underpaid. However, she was not awarded money for loss of income, nor was she reimbursed a portion of her placement debt. The employer was not penalized for underpaying her; while this was an unsatisfactory conclusion in the view of migrants' rights activists, it was nevertheless a transformative learning experience for Yolanda. She is currently working for a migrants' advisory group in Jakarta, agitating for migrants to be viewed by the Indonesian government as a legitimate labor group, eligible for protection under labor legislation, and specifically for ratification of the 1990 U.N. Convention for the Rights of Migrant Workers and Members of their Family. Yolanda's "perspective shift" (Mezirow, 1996, 2000) lead her to follow a new life, working within Indonesia for the benefit of both pre-departure and returned migrants.

\subsection{Group Suggestions Aimed at Cross-cultural Training, Financial and Educational Planning}

Everyone in the group could identify with Ester, Salama, and Yasmin (Table 2) in their desire to save money, buy homes in Indonesia and complete training. Throughout the years KOTKIHO or their uplink NGO, the Asian Migrant Centre, has offered training and workshops on financial planning aimed at eventual home or business ownership or saving for future educational or family needs. Group members felt that, while these were valuable, future workshops should also look into cooperative savings and cooperative businesses run in Indonesia for returned migrants.

\section{Conclusion}

Written and oral narratives can reveal an individual's socio-cultural, training or employment gaps or problems that have group-common elements. KOTKIHO attacks these problems on four fronts. Firstly, migrants need to claim symbolic cultural rights; to have their culture considered a rightful and respected part of Hong Kong society. In this regard, public cultural shows, sometimes in conjunction with other ethnic groups are held several times a year. In addition, migrant groups meet with Hong Kong government Culture and Leisure Department, Labor Department, Immigration Department officials, and individual legislators in planning campaigns designed to educate the public about the socio-cultural background of migrants, and the need for cross-cultural tolerance. Secondly, KOTKIHO, along with other groups, publicly demonstrate in an attempt to politicize and pressure the government over immigration and labor concerns and in order to petition for the same material rights as other migrant categories; inclusion under the minimum wage law (there is currently a separate minimum wage for domestic workers with a significantly lower salary), and permanent residents' rights (the right to pay taxes, vote and for immigration laws that do not favor employers). Thirdly, through basic English language education, Cantonese language education, and basic computer skills education, that specifically meet Indonesian work requirements and interests, a space is provided for individual growth and for the discovery of group-common problems and interests that can be acted upon for transformative change. Finally, where necessary KOTKIHO will assist individuals in confronting their employer with the aim of securing government guaranteed work benefits. In so doing, the opportunity for transformative change may be realized.

\section{References}

Ali, A., Van der Zee, K., \& Sanders, G. (2003). Determinants of intercultural adjustment among expatriate spouses. Int. J. of Intercultural Relations, 27(5), 563-580. https://doi.org/10.1016/s0147-1767(03)00054-3

Asian Migrant Centre. (2005). Underpayment: Systematic extortion of Indonesian migrant workers in Hong Kong. Hong Kong: Author.

Barna, L. (1972). Stumbling blocks in interpersonal intercultural comminications. In L. Samovar \& R. Porter (Eds.), Intercultural communications: A reader (pp. 241-245). Belmont: Wadsworth.

Barna, L. (1976). How culture shock affects communication. Paper presented at the Communication Association of the Pacific Annual Convention, Kobe, Japan.

Bayat, A. (1997). The politics of the 'informal people'. Third World Quarterly, 18(1), 53-72. https://doi.org/10.1080/01436599715055

Bell, M. M. (1997). The ghosts of place. Theory and Society, 26, 813-836. https://doi.org/10.1023/A:1006888230610

Black, J., Mendenhall, M., \& Oddou, G. (1991). Toward a comprehensive model of international adjustment: An integration of multiple theoretical perspectives. The Academy of Management Review, 16(2), 291-312. https://doi.org/10.2307/258863

Clandinin, D. J., \& Connelly, F. M. (1994). Personal experience methods. In N. K. Denzin \& Y. Lincoln (Eds.), Handbook of Qualitative Research. Thousand Oaks: Sage.

Clandinin, D. J., \& Connelly, F. M. (2000). Narrative Inquiry. San Francisco: Jossey-Bass. 
Daiute, C., \& Lightfoot, C. (Eds.). (2004). Narrative analysis: Studying the development of individuals in society. Thousand Oaks, CA: Sage. https://doi.org/10.4135/9781412985246

Deaux, K., \& Martin, D. (2003). Interpersonal networks and social categories: Specifying levels of context in identity processes. Social Psychology Quarterly, 66(2), 101-117. https://doi.org/10.2307/1519842

Friedman, P. A., Dyke, L. S., \& Murphy, S. A. (2009). Expatriate adjustment from the inside out: An autoethnographic account. International Journal of Human Resource Management, 20(2), 252-268. https://doi.org/10.1080/09585190802670524

Goss, J., \& Lindquist, B. (2000). Placing movers: An overview of the Asian-Pacific migration system. The Contemporary Pacific, 12(2), 385-414. https://doi.org/10.1353/cp.2000.0053

Hyder, A. S., \& Fregidou-Malama, M. (2009). Services marketing in a cross-cultural environment: the case of Egypt. Journal of Services Marketing, 23(4), 261-270. https://doi.org/10.1108/08876040910965593

Kiernan, P. (2010). Narrative identity in English language teaching: Exploring teacher interviews in Japanese and English.

Lyons, L. (2006). The limits of transnational activism: Organizing for migrant worker rights in Malaysia and Singapore. Paper presented at the Transnationalisation of Solidarities and Women Movements, Montreal.

Mezirow, J. (1996). Transformative dimensions of adult learning. San Francisco, CA: Jossey-Bass.

Mezirow, J. (1997). Transformative learning: Theory to practice. New Directions for Adult and Continuing Education, 74. https://doi.org/10.1002/ace.7401

Mezirow, J., \& Associates. (2000). Learning as transformation. San Francisco, CA: Jossey-Bass.

Niezen, R. (2004). A world beyond difference: Cultural identity in the age of globalization. Malden: Blackwell. https://doi.org/10.1002/9780470776582

Nyberg, R. S., \& Jensen, T. C. (2009). Honoring the Kun Lun Way. Cross-cultural organization development consulting to a hospitality company in Datong, China. Journal of applied behavioral science, 45(2), 305-337. https://doi.org/10.1177/0021886309333444

Oberg, K. (1960). Culture Shock: Adjustment to new cultural environments. Practical Anthropology., 7, 177-182. https://doi.org/10.1177/009182966000700405

Polkinghorn, D. (1988). Narrative knowing and the human sciences. NY: State University of New York Press.

Riessman, C. K. (2008). Narrative methods for the human sciences. Thousand Oaks, CA: Sage.

Slavin, L., Rainer, K., McCreary, M., \& Gowda, K. (1991). Toward a multicultural model of the stress process. Journal of Counselling and Development, 70, 156-163. https://doi.org/10.1002/j.1556-6676.1991.tb01578.x

Sobre-Denton, M., \& Hart, D. (2008). Mind the gap: Application-based analysis of cultural adjustment models. International J. of Intercultural Relations, 32(6), 538-552. https://doi.org/10.1016/j.ijintrel.2008.06.008

Sovic, S. (2009). Hi-bye friends and the herd instinct:International and home students in the creative arts. Higher Education, 58(6), 747-761. https://doi.org/10.1007/s10734-009-9223-z

Wenger, E. (1998). Communities of practice: Learning, meaning and identity. Cambridge: Cambridge University Press. https://doi.org/10.1017/CBO9780511803932

Winkelman, M. (1994). Culture shock and adaptation. Journal of Counselling and Development, 73, 121-126. https://doi.org/10.1002/j.1556-6676.1994.tb01723.x

Wong, M. M. L. (2001). Internationalizing Japanese expatriate managers - Organizational learning through international assignment. Mana. Learning, 32(2), 237-251. https://doi.org/10.1177/1350507601322005

Zhou, Y., Jindal-Snape, D., Topping, K., \& Todman, J. (2008). Theoretical models of culture shock and adaptation in international students in higher education. Studies in Higher Education, 33(1), 63-75. https://doi.org/10.1080/03075070701794833

\section{Copyrights}

Copyright for this article is retained by the author(s), with first publication rights granted to the journal.

This is an open-access article distributed under the terms and conditions of the Creative Commons Attribution license (http://creativecommons.org/licenses/by/4.0/). 